\title{
Article \\ Outcomes of Post-Operative Treatment with Concurrent Chemoradiotherapy (CRT) in High-Risk Resected Oral Cavity Squamous Cell Carcinoma (OCSCC): A Multi-Institutional Collaboration
}

\author{
Arslan Babar ${ }^{1}$, Neil M. Woody ${ }^{2}$, Ahmed I. Ghanem ${ }^{3,4}{ }^{\circledR}$, Jillian Tsai ${ }^{5}$, Neal E. Dunlap ${ }^{6}$, Matthew Schymick ${ }^{3}$, \\ Howard Y. Liu ${ }^{7} \oplus$, Brian B. Burkey ${ }^{8}$, Eric D. Lamarre ${ }^{8}$, Jamie A. $\mathrm{Ku}^{8}{ }^{8}$, Joseph Scharpf ${ }^{8}$, Brandon L. Prendes ${ }^{8}$, \\ Nikhil P. Joshi ${ }^{2}$, Jimmy J. Caudell ${ }^{9}$, Farzan Siddiqui ${ }^{3}$, Sandro V. Porceddu ${ }^{6}$, Nancy Lee ${ }^{5}$, Larisa Schwartzman ${ }^{10}$, \\ Shlomo A. Koyfman ${ }^{2}$, David J. Adelstein ${ }^{10}$ and Jessica L. Geiger ${ }^{10, *}$
}

Citation: Babar, A.; Woody, N.M.; Ghanem, A.I.; Tsai, J.; Dunlap, N.E.; Schymick, M.; Liu, H.Y.; Burkey, B.B.; Lamarre, E.D.; Ku, J.A.; et al. Outcomes of Post-Operative Treatment with Concurrent Chemoradiotherapy (CRT) in High-Risk Resected Oral Cavity Squamous Cell Carcinoma (OCSCC): A Multi-Institutional Collaboration. Curr. Oncol. 2021, 28, 2409-2419. https://doi.org/10.3390/ curroncol28040221

Received: 18 May 2021

Accepted: 23 June 2021

Published: 30 June 2021

Publisher's Note: MDPI stays neutral with regard to jurisdictional claims in published maps and institutional affiliations.

Copyright: (c) 2021 by the authors. Licensee MDPI, Basel, Switzerland. This article is an open access article distributed under the terms and conditions of the Creative Commons Attribution (CC BY) license (https:// creativecommons.org/licenses/by/ $4.0 /)$.
1 Department of Internal Medicine, Cleveland Clinic Foundation, Cleveland, OH 44195, USA; babara@ccf.org 2 Department of Radiation Oncology, Cleveland Clinic Taussig Cancer Institute, Cleveland, OH 44195, USA; woodyn@ccf.org (N.M.W.); dr.nikhil.j@gmail.com (N.P.J.); KOYFMAS@ccf.org (S.A.K.)

3 Department of Radiation Oncology, Henry Ford Cancer Institute, Detroit, MI 48202, USA; AGHANEM1@hfhs.org (A.I.G.); mschymi1@hfhs.org (M.S.); FSIDDIQ2@hfhs.org (F.S.)

4 Alexandria Clinical Oncology Department, Alexandria University, Alexandria 00203, Egypt

5 Department of Radiation Oncology, Memorial Sloan Kettering Cancer Center, New York, NY 10065, USA; tsaic@mskcc.org (J.T.); leen2@mskcc.org (N.L.)

6 Department of Radiation Oncology, University of Louisville Hospital, Louisville, KY 40202, USA; neal.dunlap@louisville.edu (N.E.D.); sandro.porceddu@health.qld.gov.au (S.V.P.)

7 Department of Radiation Oncology, Princess Alexandra Hospital, Brisbane, QLD 4102, Australia; Howard.Liu@health.qld.gov.au

8 Head and Neck Institute, Cleveland Clinic Foundation, Cleveland, OH 44195, USA; BURKEYB1@ccf.org (B.B.B.); lamarre@ccf.org (E.D.L.); KUJ@ccf.org (J.A.K.); SCHARPJ@ccf.org (J.S.); PRENDEB@ccf.org (B.L.P.)

9 Department of Radiation Oncology, H. Lee Moffitt Cancer Center and Research Institute, Tampa, FL 33612, USA; Jimmy.Caudell@moffitt.org

10 Department of Hematology and Medical Oncology, Cleveland Clinic Taussig Cancer Institute, Cleveland, OH 44195, USA; SCHWARL@ccf.org (L.S.); ADELSTD@ccf.org (D.J.A.)

* Correspondence: GEIGERJ@ccf.org

\begin{abstract}
Adjuvant chemoradiation (CRT), with high-dose cisplatin remains standard treatment for oral cavity squamous cell carcinoma (OCSCC) with high-risk pathologic features. We evaluated outcomes associated with different cisplatin dosing and schedules, concurrent with radiation (RT), and the effect of cumulative dosing of cisplatin. An IRB-approved collaborative database of patients (pts) with primary OCSCC (Stage I-IVB AJCC 7th edition) treated with primary surgical resection between January 2005 and January 2015, with or without adjuvant therapy, was established from six academic institutions. Patients were categorized by cisplatin dose and schedule, and resultant groups compared for demographic data, pathologic features, and outcomes by statistical analysis to determine disease free survival (DFS) and freedom from metastatic disease (DM). From a total sample size of 1282 pts, 196 pts were identified with high-risk features who were treated with adjuvant CRT. Administration schedule of cisplatin was not significantly associated with DFS. On multivariate (MVA), DFS was significantly better in patients without perineural invasion (PNI) and in those receiving $\geq 200 \mathrm{mg} / \mathrm{m}^{2}$ cisplatin dose $(p<0.001$ and 0.007$)$. Median DFS, by cisplatin dose, was 10.5 $\left(<200 \mathrm{mg} / \mathrm{m}^{2}\right)$ vs. $20.8 \mathrm{months}\left(\geq 200 \mathrm{mg} / \mathrm{m}^{2}\right)$. Our analysis demonstrated cumulative cisplatin dose $\geq 200 \mathrm{mg} / \mathrm{m}^{2}$ was associated with improved DFS in high-risk resected OCSCC pts.
\end{abstract}

Keywords: high risk oral cavity cancer; oral cavity squamous cell cancer; chemoradiation; cisplatin; cumulative cisplatin dose; cisplatin schedule 


\section{Introduction}

In 2004, two randomized controlled trials, Radiation Therapy Oncology Group (RTOG) 9501 and European Organization for Research and Treatment of Cancer (EORTC) 22931, reported improved outcomes when chemotherapy was added to post-operative radiotherapy (PORT) in high-risk resected head and neck squamous cell carcinoma (HNSCC) [1-3]. A combined analysis demonstrated patients with high-risk features, defined as either positive surgical margins $(\mathrm{SM}+)$ or extracapsular extension (ENE), benefitted the most from the addition of cisplatin [4]. These results established the standard of care treatment for resected high-risk HNSCC with high-dose cisplatin $\left(100 \mathrm{mg} / \mathrm{m}^{2}\right)$ every three weeks, administered concurrently with radiation (RT) [5]. However, cisplatin is highly emetogenic, nephrotoxic, ototoxic, and myelosuppresive [6,7], precluding such use in patients with significant medical co-morbidities or poor social support. Many institutions and oncologists have embraced different cisplatin schedules to deal with the toxicity, albeit with a lack of head-to-head prospective evidence supporting such alternatives as equivalent substitutes for the standard high-dose cisplatin [7]. Several studies using a weekly dosed cisplatin $40 \mathrm{mg} / \mathrm{m}^{2}$ have been reported [8-11]. Other dosing schedules include $30 \mathrm{mg} / \mathrm{m}^{2}$ weekly [12] or $50 \mathrm{mg}$ (fixed dose) weekly [13]. Daily low-dose cisplatin at $6 \mathrm{mg} / \mathrm{m}^{2}$ with RT has also been found feasible [14]. All of these regimens are administered concurrently with RT and are used in both post-operative and definitive settings.

It remains unclear if dosing schedule or total cumulative dose, during the concurrent radiation, is more important with respect to outcomes. The present study investigated cumulative cisplatin dosing and effects of cisplatin administration schedule on disease free survival (DFS), overall survival (OS), locoregional control (LRC), and freedom from metastatic disease (DM) in patients with high-risk resected oral cavity squamous cell carcinoma (OCSCC).

\section{Materials and Methods}

Patients were identified from an IRB-approved multi-institutional collaborative database of primary OCSCC (Stage I-IVB AJCC 7th edition) [15] from six academic institutions treated with primary surgical resection with or without adjuvant therapy between January 2005 and January 2015. Patients who demonstrated high-risk features of ENE and/or SM+, and who went on to receive adjuvant concurrent cisplatin, were included in this analysis and were categorized by cisplatin dose received. The resultant groups were compared for demographic data, multiple pathologic features in addition to ENE, margin assessment, and outcomes assessed by t-test and Chi-squared tests. Kaplan-Meier curves, log-rank $p$-values, and multivariate analysis (MVA) were used to determine DFS and DM. Variables with $p \leq 0.05$ on univariable Cox hazard analysis were incorporated into MVA to assess independent predictors of DFS and DM.

Variables used for MVA for DFS were perineural invasion (PNI), ENE, and cumulative cisplatin dose. Variables used for MVA for DM were PNI and cumulative cisplatin dose. DFS was defined as the time from initial diagnosis to tumor recurrence. OS was defined as time from initial diagnosis until death from any cause.

\section{Results}

\subsection{Patient Characteristics}

From a total sample size of 1282 OCSCC patients, we identified 196 (15.3\%) patients with high-risk features who were treated with concurrent chemoradiation (CRT) with cisplatin or cetuximab (Figure 1). Out of 196 patients, 181 received concurrent chemotherapy with cisplatin. Median age was 56 years; $63.3 \%$ of patients were male, $81.1 \%$ were Caucasian, $71.3 \%$ had a median 30 pack-year smoking history, $28.7 \%$ did not have a smoking history. All patients had high-risk features: $35.7 \%$ had SM+, and $83.9 \%$ had ENE. Regarding histology, $64.8 \%$ of tumors were moderately differentiated, $31.1 \%$ were poorly differentiated, and $4.1 \%$ were well differentiated. Staging information was collected: $14.3 \%$ 
were $\mathrm{T} 1,33.2 \%$ were $\mathrm{T} 2,9.7 \%$ were $\mathrm{T} 3$, and $42.8 \%$ were $\mathrm{T} 4 \mathrm{a}$ or $\mathrm{T} 4 \mathrm{~b} ; 73 \%$ were $\mathrm{N} 2 \mathrm{~b}$ or greater by AJCC 7th edition [15]. Patient characteristics are summarized in Table 1.

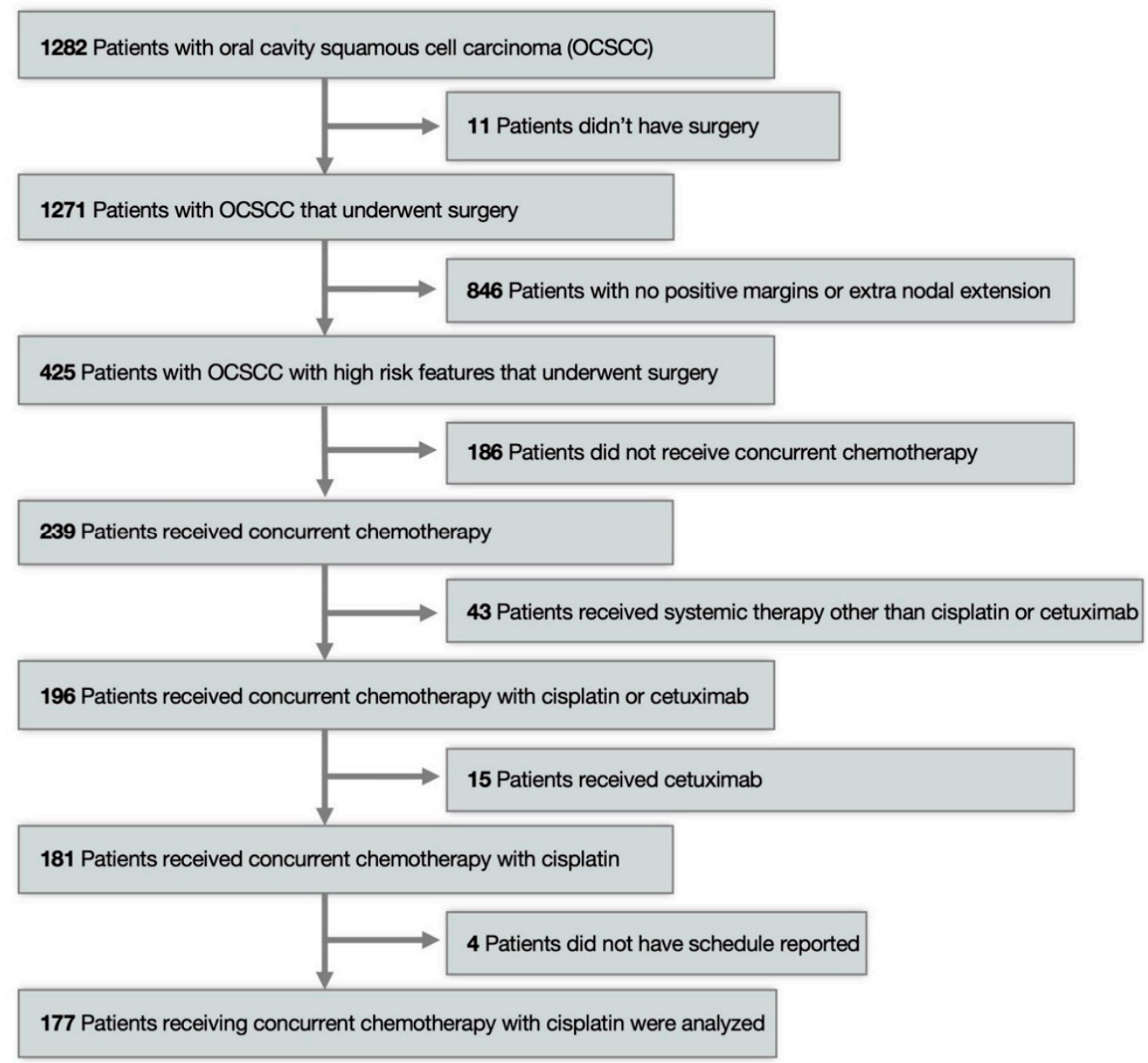

Figure 1. Patient Selection.

Table 1. Patient characteristics.

\begin{tabular}{lccc}
\hline & Characteristic & $n$ & $\%$ \\
\hline Sex & Female & 72 & 36.7 \\
& Male & 124 & 63.3 \\
\hline Race & Black & 14 & \\
& White & 159 & 8.1 \\
& Other & 23 & 11.7 \\
\hline Tobacco use (1 unknown) & & \\
Yes & 139 & 71.3 \\
No & 56 & 28.7 \\
\hline Tumor site $\quad$ & \\
Tongue & 103 & 52.6 \\
Floor of mouth & 34 & 17.3 \\
Gingiva & 19 & 9.7 \\
Buccal & 11 & 5.6 \\
Other & 17 & 8.7 \\
& 12 & 6.1 \\
\hline
\end{tabular}


Table 1. Cont.

\begin{tabular}{|c|c|c|}
\hline Characteristic & $n$ & $\%$ \\
\hline \multicolumn{3}{|l|}{ Margin status } \\
\hline Positive & 70 & 35.7 \\
\hline Negative & 126 & 64.3 \\
\hline \multicolumn{3}{|c|}{ Extranodal extension (ENE) (3 unknown) } \\
\hline Yes & 162 & 83.9 \\
\hline No & 31 & 16.1 \\
\hline \multicolumn{3}{|c|}{ Perineural invasion (PNI) (1 unknown) } \\
\hline Yes & 128 & 65.6 \\
\hline No & 67 & 34.4 \\
\hline \multicolumn{3}{|c|}{ Lymphovascular space invasion (LVSI) (3 unknown) } \\
\hline Yes & 96 & 49.7 \\
\hline No & 97 & 50.3 \\
\hline \multicolumn{3}{|l|}{ Grade } \\
\hline Well differentiated & 8 & 4.1 \\
\hline Moderately differentiated & 127 & 64.8 \\
\hline Poorly differentiated & 61 & 31.1 \\
\hline \multicolumn{3}{|l|}{ AJCC 7 pathologic $\mathrm{T}$} \\
\hline $\mathrm{T} 1$ & 28 & 14.3 \\
\hline $\mathrm{T} 2$ & 65 & 33.2 \\
\hline T3 & 19 & 9.7 \\
\hline $\mathrm{T} 4 \mathrm{a} / \mathrm{T} 4 \mathrm{~b}$ & 84 & 42.8 \\
\hline \multicolumn{3}{|l|}{ AJCC 7 pathologic $\mathrm{N}$} \\
\hline N0/no nodal dissection & 15 & 7.7 \\
\hline $\mathrm{N} 1 / \mathrm{N} 2 \mathrm{a}$ & 37 & 18.8 \\
\hline $\mathrm{N} 2 \mathrm{~b}$ & 115 & 58.7 \\
\hline $\mathrm{N} 2 \mathrm{c}$ & 28 & 14.3 \\
\hline N3 & 1 & 0.5 \\
\hline \multicolumn{3}{|l|}{ Systemic therapy } \\
\hline Cisplatin & 181 & 92.3 \\
\hline \multicolumn{3}{|l|}{ Schedule: } \\
\hline Q 3 week & 122 & 67.4 \\
\hline Q week & 55 & 30.4 \\
\hline Unknown & 4 & 2.2 \\
\hline $\begin{array}{c}\text { Non-cisplatin-based } \\
\text { chemotherapy (cetuximab) }\end{array}$ & 15 & 7.7 \\
\hline \multicolumn{3}{|c|}{ Cisplatin dose received: Median: $200 \mathrm{mg} / \mathrm{m}^{2}$ (range $80-300$ ) } \\
\hline$\geq 200 \mathrm{mg} / \mathrm{m}^{2}$ & 158 & 87.4 \\
\hline$<200 \mathrm{mg} / \mathrm{m}^{2}$ & 23 & 12.6 \\
\hline Radiation dose received: $\mathrm{Mec}$ & e 10 & \\
\hline
\end{tabular}

\subsection{Treatment}

All patients underwent surgical resection; $96.9 \%$ patients underwent surgical resection with lymph node dissection, and 3.1\% underwent surgical resection without lymph node dissection.

A total of 181 patients (92.3\%) of the cohort received concurrent cisplatin and radiation in this analysis: $67.4 \%$ (122 pts) received high-dose cisplatin, and 30.4\% (55 pts) received weekly cisplatin $40 \mathrm{mg} / \mathrm{m}^{2}$. In four patients, the cisplatin schedule was not identified, and 15 patients received cetuximab. Median dose of RT delivered was 66 Gray (Gy).

The estimated 3-year and 5-year overall survival (OS) rates for the whole cohort were $51 \%$ and $45.7 \%$, respectively. On univariate analysis, OS was significantly worse in patients with PNI (HR: $1.9,95 \%$ CI 1.2 to $2.9, p=0.003$ ) and with lymphovascular space invasion (LVSI) (HR: 1.7, 95\% CI 1.1 to 2.4, $p=0.003$ ). The OS was better with the radiation dose (per 
10 Gy) received (HR: $0.75,95 \%$ CI 0.631 to $0.89, p=0.002$ ). On univariate analysis, LRC was worse with the presence of PNI (HR: 2.09, 95\% CI 1.2 to $3.6, p=0.008$ ). DM was worse with PNI (HR: $2.6,95 \%$ CI 1.3 to $5.3, p=0.005$ ), LVSI (HR: 2.5, 95\% CI 1.4 to $4.6, p=0.002$ ), and ECE (HR: $2.9,95 \%$ CI 1.1 to $8.3, p=0.03$ ). DFS was significantly better with higher cisplatin dose received (HR: $0.4,95 \%$ CI 0.91 to $0.99, p=0.013$ ) and higher RT dose delivered (HR: $0.9,95 \%$ CI 0.95 to $0.99, p=0.008$ ), and worse with PNI (HR: $1.9,95 \%$ CI 1.2 to $2.8, p=0.002$ ) and LVSI (HR: 1.4, 95\% CI 1.1 to $2.1 p=0.031$ ).

On MVA, DFS was significantly better with higher cisplatin dose (HR: 0.95, 95\% CI 0.914 to 0.99 per $100 \mathrm{mg} / \mathrm{m}^{2}$ increase in cisplatin, $p=0.007$ ) and absence of PNI (HR: 3.1, 95\% CI 1.7 to 5.5, $p<0.001$ ) (Table 2). Median DFS was significantly better with higher cisplatin cumulative dose: 10.5 months for $<200 \mathrm{mg} / \mathrm{m}^{2} \mathrm{vs}$. 20.8 months for $\geq 200 \mathrm{mg} / \mathrm{m}^{2}$ $(p=0.013)$ (Figure 2). Median OS by cisplatin cumulative dose was not significantly different $(p=0.187)$. DM was significantly higher in patients with PNI (HR: $2.7,95 \%$ CI 1.1 to $6.5, p=0.031$ ). There was a trend towards improved outcomes with higher cumulative cisplatin dose delivered: OS $(p=0.187), \operatorname{LRC}(p=0.131)$, and DM $(p=0.084)$. Cisplatin administration schedule (weekly vs. every 3 weeks) was not associated with significant effect on DFS (HR: $0.618,95 \%$ CI 0.59 to 1.36 ).

Table 2. Multivariate disease-free survival (DFS).

\begin{tabular}{cccc}
\hline Treatment Characteristics & $\begin{array}{c}\text { Hazard Ratio } \\
\text { (HR) }\end{array}$ & $\begin{array}{c}\text { 95\% Confidence } \\
\text { Interval (CI) }\end{array}$ & $p$-Value \\
\hline $\begin{array}{c}\text { Cisplatin (CDDP) dose received } \\
\text { (per 100 } \mathrm{mg} / \mathrm{m}^{2} \text { ) }\end{array}$ & 0.951 & $0.914-0.990$ & 0.007 \\
Perineural invasion (PNI) & 3.077 & $1.706-5.525$ & $<0.001$ \\
\hline
\end{tabular}

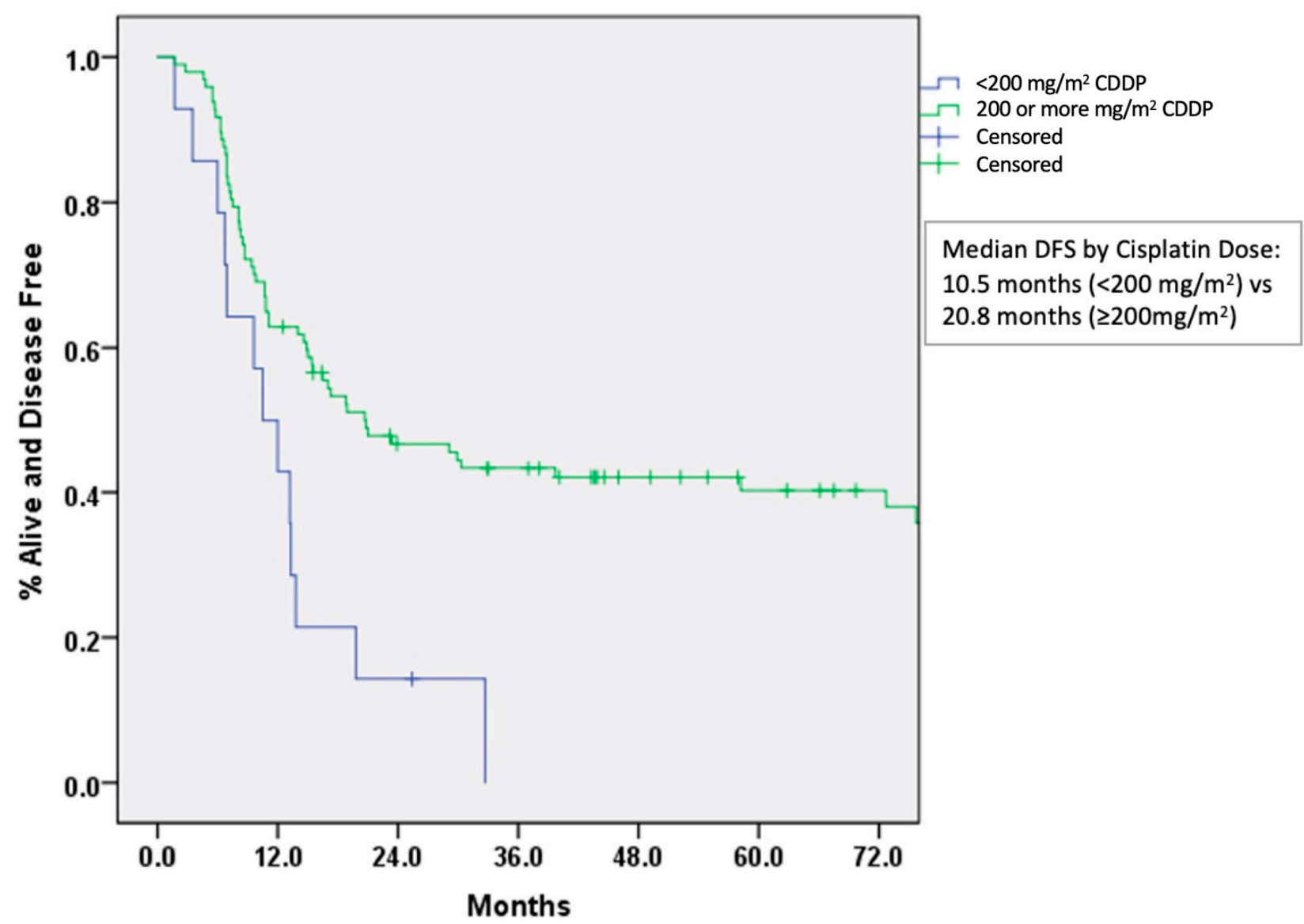

Figure 2. Disease free survival by dose of concurrent cisplatin. Abbreviations: CDDP, Cisplatin; DFS, Disease free survival. 


\section{Discussion}

High-dose cisplatin added to adjuvant RT is the standard chemotherapy for highrisk resected OCSCC, with a benefit in survival outcomes compared with adjuvant RT alone $[1,3,4]$. However, concern for toxicities has led to questions regarding alternative dosing strategies to maintain optimal survival outcomes while mitigating such adverse effects. Retrospective data support use of both schedules in this disease $[16,17]$ and prospective data demonstrate non-inferiority of weekly cisplatin in high-risk locally advanced HNSCC [18].

Similarly, our data, evaluating one of the largest cohorts for OCSCC, treated using modern modalities, demonstrate no difference in DFS with respect to cisplatin administration schedule (weekly vs. once every three weeks). Total cumulative dose is more important, with patients receiving $\geq 200 \mathrm{mg} / \mathrm{m}^{2}$ of cisplatin demonstrating improved DFS in our cohort of high-risk resected OCSCC patients. Though not statistically significant, a trend was also noticed towards improved LRC and OS in patients who received a $\geq 200 \mathrm{mg} / \mathrm{m}^{2}$ cumulative dose.

These data are reassuring, as high-dose cisplatin can be very toxic with a multitude of short- and long-term side effects, which may limit its use in vulnerable patients $[18,19]$. Weekly cisplatin may be a feasible alternative for patients unable to tolerate the threeweekly high-dose regimen $[9,10,12,13]$.

Prospective data, comparing cisplatin dosing schedules, have also been published $[18,19]$. A phase-III randomized non-inferiority trial, published in 2017, reported data supporting three-week cisplatin [19]. An overwhelming majority of patients were oral cavity (87\%) and received adjuvant CRT (total 93\%). Two-year LRC was significantly better in the cohort that received high-dose three-weekly cisplatin (73.1 vs. $58.5 \%, p=0.014)$. Of note, the median cumulative cisplatin dose in the weekly cohort was $210 \mathrm{mg} / \mathrm{m}^{2}$ compared with $300 \mathrm{mg} / \mathrm{m}^{2}$ in the three-weekly cohort. Grade 3, or higher, toxicities occurred more frequently in the high-dose cisplatin group $(84.6 \%$ vs. $71.6 \%, p=0.006)$. Outcomes from retrospective and prospective studies, comparing weekly versus three-weekly cisplatin, are summarized in Table 3, including the recently published Japan Clinical Oncology Group study (JCOG1008) [18] demonstrating non-inferiority of weekly cisplatin. 


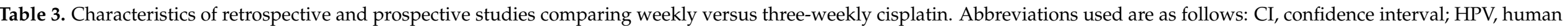
papillomavirus; HR, hazard ratio; LRC, locoregional control; NR, not reported; OS, overall survival; PFS, progression free survival; RFS, recurrence free survival.

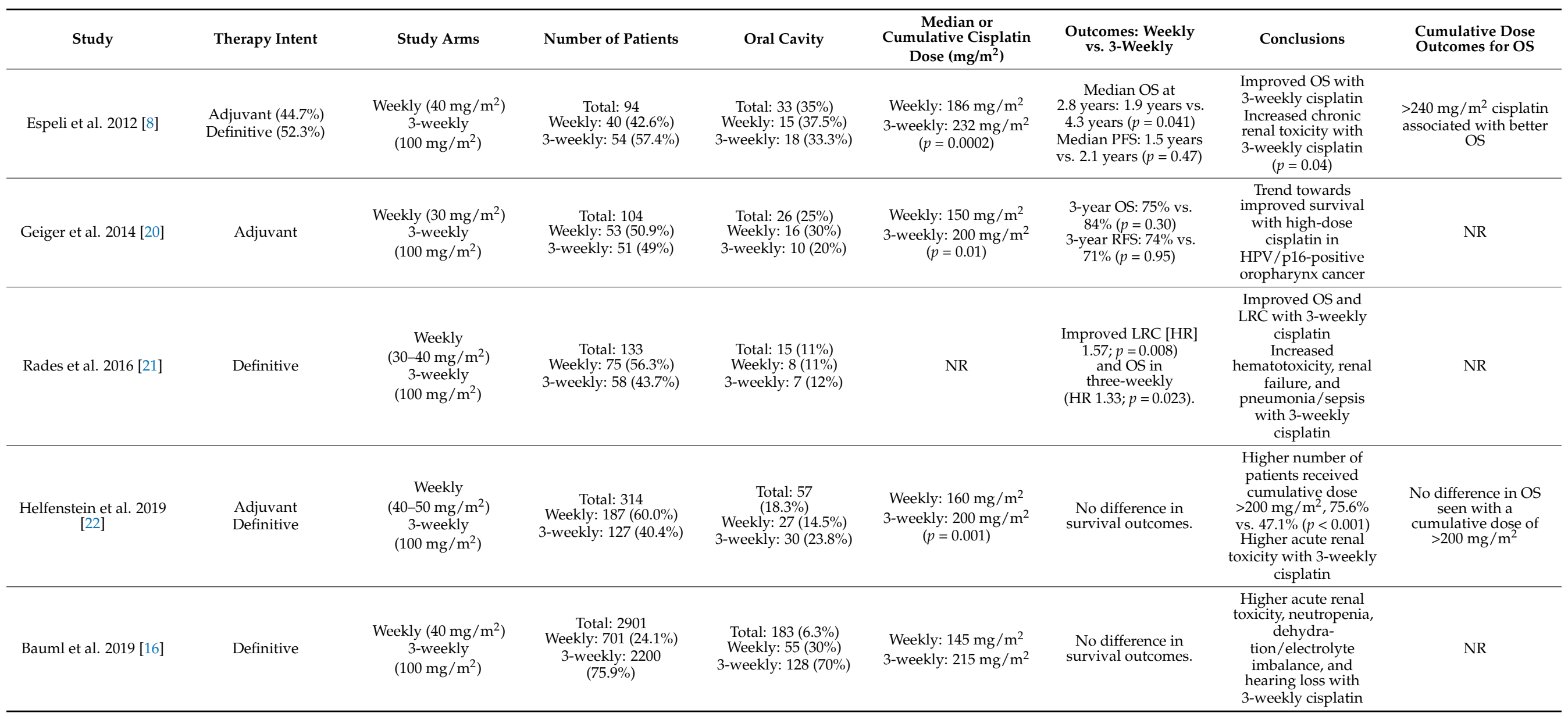


Table 3. Cont

\begin{tabular}{|c|c|c|c|c|c|c|c|c|}
\hline Study & Therapy Intent & Study Arms & Number of Patients & Oral Cavity & $\begin{array}{c}\text { Median or } \\
\text { Cumulative Cisplatin } \\
\text { Dose }\left(\mathrm{mg} / \mathrm{m}^{2}\right)\end{array}$ & $\begin{array}{l}\text { Outcomes: Weekly } \\
\text { vs. 3-Weekly }\end{array}$ & Conclusions & $\begin{array}{l}\text { Cumulative Dose } \\
\text { Outcomes for OS }\end{array}$ \\
\hline $\begin{array}{l}\text { Mohamed et al. } 2019 \\
\text { [17] } \\
39 \text { studies included in } \\
\text { the comparative } \\
\text { analysis. }\end{array}$ & Definitive & $\begin{array}{c}\text { Weekly }\left(40 \mathrm{mg} / \mathrm{m}^{2}\right) \\
\text { 3-weekly } \\
\left(100 \mathrm{mg} / \mathrm{m}^{2}\right)\end{array}$ & $\begin{array}{c}\text { Total: } 3668 \\
\text { Weekly: } 1186(32 \%) \\
\text { 3-weekly: } 2482(67 \%)\end{array}$ & NR & $\begin{array}{l}\text { Weekly: } 200 \mathrm{mg} / \mathrm{m}^{2} \\
\text { 3-weekly: } 300 \mathrm{mg} / \mathrm{m}^{2}\end{array}$ & $\begin{array}{c}\text { Similar OS at } 2 \text { years: } \\
74 \% \text { vs. 67\% }(p=0.67) \\
\text { Similar LRC: } 58 \% \text { vs. } \\
61 \%(p=0.7) \\
\text { Similar } 2 \text {-year PFS: } \\
69 \% \text { vs. } 62 \%(p=0.9)\end{array}$ & $\begin{array}{c}\text { Weekly cisplatin } \\
\text { comparable in efficacy } \\
\text { and safety to } \\
\text { 3-weekly cisplatin }\end{array}$ & NR \\
\hline $\begin{array}{c}\text { Noronha et al. } 2017 \\
{[19]}\end{array}$ & $\begin{array}{l}\text { Adjuvant (93\%) } \\
\text { Definitive (7\%) }\end{array}$ & $\begin{array}{c}\text { Weekly }\left(30 \mathrm{mg} / \mathrm{m}^{2}\right) \\
\text { 3-weekly } \\
\left(100 \mathrm{mg} / \mathrm{m}^{2}\right)\end{array}$ & $\begin{array}{l}\text { Total: } 300 \\
\text { Weekly: } 150 \\
\text { 3-weekly: } 150\end{array}$ & $\begin{array}{c}\text { Oral cavity: } 262(87 \%) \\
\text { Weekly: } 136 \\
\text { 3-weekly: } 126\end{array}$ & $\begin{array}{c}\text { Weekly: } \\
\text { 180-200 mg/m² } \\
\text { 3-weekly: } 300 \mathrm{mg} / \mathrm{m}^{2}\end{array}$ & $\begin{array}{c}\text { Trend towards better } \\
\text { OS in 3-weekly. } \\
\text { Median OS } \\
\text { 39.5 months in weekly. } \\
\text { Median OS not } \\
\text { reached in 3-weekly. } \\
\text { HR }(1.14[95 \% \text { CI, } 0.79 \\
\text { to } 1.65] ; p=0.48) . \\
\text { LRC better in } \\
\text { 3-weekly vs. weekly: } \\
\text { 73.1\% vs. 58.5\%, } \\
\text { (p=0.014) }\end{array}$ & $\begin{array}{c}\text { Better LRC in } \\
\text { 3-weekly vs. weekly } \\
\text { Higher grade-3 } \\
\text { toxicities in 3-weekly } \\
\text { vs. weekly, 84.6\% vs. } \\
71.6 \%(p=0.006)\end{array}$ & NR \\
\hline $\begin{array}{c}\text { Kunieda et al. } 2014 \\
\text { [18] } \\
\text { Phas II/III trial } \\
\text { (JCOG1008) }\end{array}$ & Adjuvant & $\begin{array}{c}\text { Weekly }\left(40 \mathrm{mg} / \mathrm{m}^{2}\right) \\
\text { 3-weekly } \\
\left(100 \mathrm{mg} / \mathrm{m}^{2}\right)\end{array}$ & $\begin{array}{c}\text { Total: } 261 \\
\text { Weekly: } 129(49.5 \%) \\
\text { 3-weekly: } 132(50.5 \%)\end{array}$ & NR & $\begin{array}{l}\text { Weekly: } 239 \mathrm{mg} / \mathrm{m}^{2} \\
\text { 3-weekly: } 280 \mathrm{mg} / \mathrm{m}^{2}\end{array}$ & $\begin{array}{c}\text { 3-year OS in 3-weekly } \\
\text { vs. weekly, 59.1\% vs. } \\
71.5 \%[\mathrm{HR}, 0.69 \\
(99.1 \% \mathrm{CI}, 0.374-1.273 \\
{[<1.32]} \\
p \text { for non-inferiority = } \\
0.00272[<0.00433]\end{array}$ & $\begin{array}{l}\text { Weekly cisplatin is } \\
\text { non-inferior to } \\
\text { 3-weekly cisplatin. } \\
\text { Higher kidney injury, } \\
\text { neutropenia, and } \\
\text { mucositis in 3-weekly } \\
\text { arm }\end{array}$ & NR \\
\hline
\end{tabular}


While there is new support for alternative cisplatin dosing schedules, there is a paucity of literature on the optimal cumulative dose of cisplatin, but some studies have suggested that it may have a more significant impact on overall survival than the cisplatin dosing schedule used $[23,24]$.

One systematic review, based on six phase-III trials of definitive CRT, found a statistically significant association between OS and cumulative cisplatin dose $(p=0.027)$ [25]. This review concluded that a survival benefit was shown at $140-200 \mathrm{mg} / \mathrm{m}^{2}$, that higher cumulative dose resulted in greater benefit, and that a cumulative dose of at least $200 \mathrm{mg} / \mathrm{m}^{2}$ cisplatin is recommended.

In the definitive setting, two retrospective studies compared high-dose and lowdose cisplatin and found no significant difference in OS between the two groups [16,26]. However, one of the retrospective studies found that, when analysis was limited to human papilloma virus-negative (HPV-) locally advanced head and neck cancers, a cumulative dose of greater than $200 \mathrm{mg} / \mathrm{m}^{2}$ had a statistically significant effect on OS [26]. Our study, similarly, found a trend toward OS improvement in resected oral cavity cancers.

A recent multi-center retrospective study done in Switzerland included 314 patients with advanced HNSCC, including $18.3 \%$ oral cavity, treated with combined CRT in the adjuvant $(35.1 \%)$ and definitive $(64.9 \%)$ settings, at three different centers between 2008 and 2015 [22]. The study failed to find a significant association between cisplatin dose of $\geq 200 \mathrm{mg} / \mathrm{m}^{2}$ and improved OS or progression free survival (PFS). It did, however, show that more patients treated with the high-dose three-weekly regimen were able to receive a dose of $\geq 200 \mathrm{mg} / \mathrm{m}^{2}$.

Overall, these studies suggest that a cumulative dose of $\geq 200 \mathrm{mg} / \mathrm{m}^{2}$ cisplatin confers an OS benefit compared to $<200 \mathrm{mg} / \mathrm{m}^{2}$; however, it is unclear if further dose increase confers further OS benefit.

In our study, we evaluated outcomes associated with different cisplatin schedules, concurrent with radiotherapy, and the effect of cumulative dosing of cisplatin. Our findings largely align with the general trends observed above, indicating the importance of a cumulative dose of $\geq 200 \mathrm{mg} / \mathrm{m}^{2}$ cisplatin, though with varying degrees of significance for the variables measuring treatment success (DFS, OS, LRC, and DM). Most significantly, our study demonstrated that a higher dose of cisplatin significantly improved DFS, which has not been reported in previous studies.

Furthermore, our results also indicated a trend associating higher cisplatin dose with improved OS ( $p=0.187)$. However, we did not observe a statistically significant improvement in OS with the higher dose.

Multiple studies have shown that the presence of PNI in HNSCC has been associated with worse survival outcomes [27-29]. Similarly our study also showed that the presence of PNI was associated with worse OS, DFS, LRC, and DM.

Selection bias serves as a limitation on this study. Conceivably, patients selected for high-dose chemotherapy are likely younger and in better health, able to undergo more rigorous treatment. In this case, age and health status could have acted as confounding variables.

\section{Conclusions}

Based on our multi-institution collaborative cohort of retrospective data, we found that a dose of $\geq 200 \mathrm{mg} / \mathrm{m}^{2}$ of cisplatin had a significant impact on DFS in high-risk resected OCSCC. Our study is one of the largest of its kind and one of the first to report on the association between cumulative dosing and survival outcomes in the adjuvant setting. Cisplatin administration schedule (weekly vs. every 3 weeks) was not associated with significant effect on DFS. Our study also showed that the presence of PNI was associated with worse survival outcomes. A randomized controlled trial would be required to better define the effects of cumulative dose on survival outcomes in the adjuvant setting. 
Author Contributions: Conceptualization, A.B., N.M.W. and J.L.G.; methodology, A.B., N.M.W. and J.L.G.; software, N.M.W.; validation, N.M.W., A.B. and J.J.C.; formal analysis, N.M.W.; investigation, A.B., N.M.W., D.J.A. and J.L.G.; resources, A.B., N.M.W., A.I.G., J.T., N.E.D., M.S., H.Y.L., B.B.B., E.D.L., J.A.K., J.S., B.L.P., N.P.J., J.J.C., F.S., S.V.P., N.L., L.S., S.A.K., D.J.A. and J.L.G.; data curation, A.B. and J.L.G.; writing-original draft preparation, A.B. and J.L.G.; writing-A.B.; N.M.W.; A.I.G.; J.T.; N.E.D.; M.S.; H.Y.L.; B.B.B.; E.D.L.; J.A.K.; J.S.; B.L.P.; N.P.J.; J.J.C.; F.S.; S.V.P.; N.L.; L.S.; S.A.K.; D.J.A.; J.L.G.; visualization, A.B and J.L.G.; supervision, J.L.G. and. D.J.A.; project administration, J.L.G. All authors have read and agreed to the published version of the manuscript.

Funding: This research received no external funding.

Institutional Review Board Statement: Not applicable.

Informed Consent Statement: Patient consent was waived as patients were identified from an IRB approved multi-institutional collaborative database of primary OCSCC.

Data Availability Statement: The data presented in this study are available on request from the corresponding author.

Conflicts of Interest: Farzan Siddiqui reports Honoraria for lectures and travel reimbursement from Varian Medical Systems (unrelated to current work); Medical advisory board from Varian Noona. Jimmy J. Caudell reports COI from Varian Medical Systems (outside submitted work). The rest declare no conflict of interest.

\section{References}

1. Cooper, J.S.; Pajak, T.F.; Forastiere, A.A.; Jacobs, J.; Campbell, B.H.; Saxman, S.B.; Kish, J.A.; Kim, H.E.; Cmelak, A.J.; Rotman, M.; et al. Postoperative concurrent radiotherapy and chemotherapy for high-risk squamous-cell carcinoma of the head and neck. $N$. Engl. J. Med. 2004, 350, 1937-1944. [CrossRef]

2. Cooper, J.S.; Zhang, Q.; Pajak, T.F.; Forastiere, A.A.; Jacobs, J.; Saxman, S.B.; Kish, J.A.; Kim, H.E.; Cmelak, A.J.; Rotman, M.; et al. Long-term follow-up of the RTOG 9501/intergroup phase III trial: Postoperative concurrent radiation therapy and chemotherapy in high-risk squamous cell carcinoma of the head and neck. Int. J. Radiat. Oncol. Biol. Phys. 2012, 84, 1198-1205. [CrossRef]

3. Bernier, J.; Domenge, C.; Ozsahin, M.; Matuszewska, K.; Lefèbvre, J.L.; Greiner, R.H.; Giralt, J.; Maingon, P.; Rolland, F.; Bolla, M.; et al. Postoperative irradiation with or without concomitant chemotherapy for locally advanced head and neck cancer. N. Engl. J. Med. 2004, 350, 1945-1952. [CrossRef]

4. Bernier, J.; Cooper, J.S.; Pajak, T.F.; van Glabbeke, M.; Bourhis, J.; Forastiere, A.; Ozsahin, E.M.; Jacobs, J.R.; Jassem, J.; Ang, K.K.; et al. Defining risk levels in locally advanced head and neck cancers: A comparative analysis of concurrent postoperative radiation plus chemotherapy trials of the EORTC (\#22931) and RTOG (\# 9501). Head Neck 2005, 27, 843-850. [CrossRef] [PubMed]

5. National Comprehensive Cancer Network. NCCN Clinical Practice Guidelines in Oncology: Head and Neck Cancers, Version 2. 2019. Available online: https://www.nccn.org/professionals/physician_gls/pdf/head-and-neck.pdf (accessed on 4 August 2019).

6. Zuur, C.L.; Simis, Y.J.; Verkaik, R.S.; Schornagel, J.H.; Balm, A.J.; Dreschler, W.A.; Rasch, C.R. Hearing loss due to concurrent daily low-dose cisplatin chemoradiation for locally advanced head and neck cancer. Radiother. Oncol. 2008, 89, 38-43. [CrossRef] [PubMed]

7. Szturz, P.; Wouters, K.; Kiyota, N.; Tahara, M.; Prabhash, K.; Noronha, V.; Adelstein, D.; Van Gestel, D.; Vermorken, J.B. Low-Dose vs. High-Dose Cisplatin: Lessons Learned From 59 Chemoradiotherapy Trials in Head and Neck Cancer. Front. Oncol. 2019, 9, 86. [CrossRef]

8. Espeli, V.; Zucca, E.; Ghielmini, M.; Giannini, O.; Salatino, A.; Martucci, F.; Richetti, A. Weekly and 3-weekly cisplatin concurrent with intensity-modulated radiotherapy in locally advanced head and neck squamous cell cancer. Oral Oncol. 2012, 48, 266-271. [CrossRef] [PubMed]

9. Homma, A.; Inamura, N.; Oridate, N.; Suzuki, S.; Hatakeyama, H.; Mizumachi, T.; Kano, S.; Sakashita, T.; Onimaru, R.; Yasuda, K.; et al. Concomitant weekly cisplatin and radiotherapy for head and neck cancer. Jpn. J. Clin. Oncol. 2011, 41, 980-986. [CrossRef] [PubMed]

10. Otty, Z.; Skinner, M.B.; Dass, J.; Collins, M.; Mooi, J.; Thuraisingam, K.; Sabesan, S. Efficacy and tolerability of weekly low-dose cisplatin concurrent with radiotherapy in head and neck cancer patients. Asia Pac. J. Clin. Oncol. 2011, 7, 287-292. [CrossRef]

11. Sharma, A.; Mohanti, B.K.; Thakar, A.; Bahadur, S.; Bhasker, S. Concomitant chemoradiation versus radical radiotherapy in advanced squamous cell carcinoma of oropharynx and nasopharynx using weekly cisplatin: A phase II randomized trial. Ann. Oncol. Off. J. Eur. Soc. Med. Oncol. 2010, 21, 2272-2277. [CrossRef]

12. Rampino, M.; Ricardi, U.; Munoz, F.; Reali, A.; Barone, C.; Musu, A.R.; Balcet, V.; Franco, P.; Grillo, R.; Bustreo, S.; et al. Concomitant adjuvant chemoradiotherapy with weekly low-dose cisplatin for high-risk squamous cell carcinoma of the head and neck: A phase II prospective trial. Clin. Oncol. (R. Coll. Radiol.) 2011, 23, 134-140. [CrossRef] [PubMed] 
13. Bachaud, J.M.; Cohen-Jonathan, E.; Alzieu, C.; David, J.M.; Serrano, E.; Daly-Schveitzer, N. Combined postoperative radiotherapy and weekly cisplatin infusion for locally advanced head and neck carcinoma: Final report of a randomized trial. Int. J. Radiat. Oncol. Biol. Phys. 1996, 36, 999-1004. [CrossRef]

14. Wolff, H.A.; Overbeck, T.; Roedel, R.M.; Hermann, R.M.; Herrmann, M.K.; Kertesz, T.; Vorwerk, H.; Hille, A.; Matthias, C.; Hess, C.F.; et al. Toxicity of daily low dose cisplatin in radiochemotherapy for locally advanced head and neck cancer. J. Cancer Res. Clin. Oncol. 2009, 135, 961-967. [CrossRef]

15. Edge, S.B.; Byrd, D.R.; Compton, C.C.; Fritz, A.G.; Greene, F.L.; Trotti, A. (Eds.) American Joint Committee on Cancer (AJCC). In AJCC Cancer Staging Manual, 7th ed.; Springer International Publishing: Cham, Switzerland, 2010; Volume 17, pp. 1471-1474.

16. Bauml, J.M.; Vinnakota, R.; Anna Park, Y.H.; Bates, S.E.; Fojo, T.; Aggarwal, C.; Limaye, S.; Damjanov, N.; Di Stefano, J.; Ciunci, C.; et al. Cisplatin Every 3 Weeks Versus Weekly With Definitive Concurrent Radiotherapy for Squamous Cell Carcinoma of the Head and Neck. JNCI J. Natl. Cancer Inst. 2019, 111, 490-497. [CrossRef]

17. Mohamed, A.; Twardy, B.; Zordok, M.A.; Ashraf, K.; Alkhoder, A.; Schrapp, K.; Steuer, C.; Chen, Z.; Pakkala, S.; Pillai, R.; et al. Concurrent chemoradiotherapy with weekly versus triweekly cisplatin in locally advanced squamous cell carcinoma of the head and neck: Comparative analysis. Head Neck 2019, 41, 1490-1498. [CrossRef] [PubMed]

18. Kunieda, F.; Kiyota, N.; Tahara, M.; Kodaira, T.; Hayashi, R.; Ishikura, S.; Mizusawa, J.; Nakamura, K.; Fukuda, H.; Fujii, M.; et al. Randomized Phase II/III Trial of Post-operative Chemoradiotherapy Comparing 3-Weekly Cisplatin with Weekly Cisplatin in High-risk Patients with Squamous Cell Carcinoma of Head and Neck: Japan Clinical Oncology Group Study (JCOG1008). Jpn. J. Clin. Oncol. 2014, 44, 770-774. [CrossRef]

19. Noronha, V.; Joshi, A.; Patil, V.M.; Agarwal, J.; Ghosh-Laskar, S.; Budrukkar, A.; Murthy, V.; Gupta, T.; D'Cruz, A.K.; Banavali, S.; et al. Once-a-Week Versus Once-Every-3-Weeks Cisplatin Chemoradiation for Locally Advanced Head and Neck Cancer: A Phase III Randomized Noninferiority Trial. J. Clin. Oncol. 2018, 36, 1064-1072. [CrossRef]

20. Geiger, J.L.; Lazim, A.F.; Walsh, F.J.; Foote, R.L.; Moore, E.J.; Okuno, S.H.; Olsen, K.D.; Kasperbauer, J.L.; Price, D.L.; Garces, Y.I.; et al. Adjuvant chemoradiation therapy with high-dose versus weekly cisplatin for resected, locally-advanced HPV/p16-positive and negative head and neck squamous cell carcinoma. Oral Oncol. 2014, 50, 311-318. [CrossRef]

21. Rades, D.; Seidl, D.; Janssen, S.; Bajrovic, A.; Karner, K.; Strojan, P. Schild SE.Comparison of weekly administration of cisplatin versus three courses of cisplatin $100 \mathrm{mg} / \mathrm{m}^{2}$ for definitive radiochemotherapy of locally advanced head-and-neck cancers. BMC Cancer 2016, 16, 437. [CrossRef]

22. Helfenstein, S.; Riesterer, O.; Meier, U.R.; Papachristofilou, A.; Kasenda, B.; Pless, M.; Rothschild, S.I. 3-weekly or weekly cisplatin concurrently with radiotherapy for patients with squamous cell carcinoma of the head and neck-A multicentre, retrospective analysis. Radiat. Oncol. 2019, 14, 32. [CrossRef] [PubMed]

23. Ang, K.; Zhang, Q.; Wheeler, R.H.; Rosenthal, D.I.; Nguyen-Tan, F.; Lu, C.; Kim, H.; Axelrod, R.S.; Silverman, C.I.; Weber, R.S. A phase III trial (RTOG 0129) of two radiation-cisplatin regimens for head and neck carcinomas (HNC): Impact of radiation and cisplatin intensity on outcome. J. Clin. Oncol. 2010, 28, 5507. [CrossRef]

24. Pignon, J.-P.; le Maître, A.; Maillard, E.; Bourhis, J. MACH-NC Collaborative Group. Meta-analysis of chemotherapy in head and neck cancer (MACH-NC): An update on 93 randomised trials and 17,346 patients. Radiother. Oncol. 2009, 92, 4-14. [CrossRef] [PubMed]

25. Strojan, P.; Vermorken, J.B.; Beitler, J.J.; Saba, N.F.; Haigentz, M., Jr.; Bossi, P.; Worden, F.P.; Langendijk, J.A.; Eisbruch, A.; Mendenhall, W.M.; et al. Cumulative cisplatin dose in concurrent chemoradiotherapy for head and neck cancer: A systematic review. Head Neck 2016, 38, E2151-E2158. [CrossRef] [PubMed]

26. Spreafico, A.; Huang, S.H.; Xu, W.; Granata, R.; Liu, C.S.; Waldron, J.N.; Chen, E.; Ringash, J.; Bayley, A.; Chan, K.K.; et al. Impact of cisplatin dose intensity on human papillomavirus-related and -unrelated locally advanced head and neck squamous cell carcinoma. Eur. J. Cancer 2016, 67, 174-182. [CrossRef] [PubMed]

27. Chinn, S.B.; Spector, M.E.; Bellile, E.L.; McHugh, J.B.; Gernon, T.J.; Bradford, C.R.; Wolf, G.T.; Eisbruch, A.; Chepeha, D.B. Impact of perineural invasion in the pathologically N0 neck in oral cavity squamous cell carcinoma. Otolaryngol. Head Neck Surg. 2013, 149, 893-899. [CrossRef] [PubMed]

28. Fagan, J.J.; Collins, B.; Barnes, L.; D’Amico, F.; Myers, E.N.; Johnson, J.T. Perineural invasion in squamous cell carcinoma of the head and neck. Arch. Otolaryngol. Head Neck Surg. 1998, 124, 637-640. [CrossRef] [PubMed]

29. Soo, K.C.; Carter, R.L.; O’Brien, C.J.; Barr, L.; Bliss, J.M.; Shaw, H.J. Prognostic implications of perineural spread in squamous carcinomas of the head and neck. Laryngoscope 1986, 96, 1145-1148. [CrossRef] 